\title{
Religious debate continues
}

SIR-R. A. Savidge ${ }^{1}$ and R. S. Courtney ${ }^{2}$ criticize M. Vaneechoutte's carefully constructed hypothesis on the memetic basis of religion too strongly ${ }^{3}$. They have overlooked several points.

First, Christianity is only one of a large number of religions (including my own, Sikhism ${ }^{4}$ ). The fact that individuals in different parts of the world, left to themselves, have chosen to follow a variety of religions, suggests the strong desire to embrace such a meme. As a cynic once said, "God created Man, and Man, being a gentleman, returned the compliment".

Second, it is by no means clear that the Bible is a literal record of events that can be used as scientific evidence. Recent theological research suggests that much of the Bible is the result of wishful thinking by Jesus's followers ${ }^{5}$. Most of the miracles described (including turning water into wine) probably never occurred. A deep desire to believe in miracles, relics and places of pilgrimage appears to be a universal human trait; their widespread appeal appears secondary to memereinforcement.

Last, there is a large dichotomy between the preaching and practice of Christianity. The idea that only followers of the Christian faith have the opportunity to be "saved" (while the rest of us, presumably, go to Hell) appears to me to be a particularly self-centred example of meme-reinforcement. History does not abound with examples of Christians who "turned the other cheek". Instead, the physical elimination, or religious conversion, of those with conflicting memes seems to have been the norm.

To conclude, memes are essential to our security and psychological well-being; thus it is understandable that when a meme comes under threat the reaction varies from literary abuse to physical violence. This helps to explain why scientists who appear sensible in day-to-day life get so hot under the collar about their religion (or lack of it, for even atheism could be regarded as a meme. . .).

\section{VIkram]it S. Kanwar}

667 Harbor Edge Circle, Apt 202,

Memphis, Tennessee 38103, USA

SIR - One cannot but agree with R. S. Courtney ${ }^{2}$ on peer review for pieces about religion. Thus the parable of the Good Samaritan ${ }^{6}$ is not necessarily about the compassionate care of a Samaritan for a Jew. In none of the four versions of the New Testament to which I have access (the Authorized Version, the New English Bible, the New Standard Version and the Good News Bible) is the man for whom the Samaritan cares identified as a Jew. Surely the point of the parable is that a Samaritan (that is, a member of a lowly regarded Jewish sect) gives succour to the injured man whereas the priest and the Levite (Sadducees/Pharisees?) passed him by. So indeed the parable might be about compassionate care but not about non-Jew for Jew (possibly the reverse). Alternatively it might well be just scoring points against the religious establishment.

\section{R. Leberman}

11 Avenue Bougault,

38640 Claix, France

SIR - I would like to ask R. A. Savidge whether he has a scientific proof that the transformation of $\mathrm{H}_{2} \mathrm{O}$ into $\mathrm{CH}_{3} \mathrm{CH}_{2} \mathrm{OH}$ really happened. The New Testament was written in Greek by the four evangelists between the years 70 and 100 of the Christian era, about 40 to 70 years after the death of Jesus. It is embellished by hearsay, mainly of non-contemporaries, not of eye-witnesses. For a scientifically minded non-Christian and nonbeliever, the Gospel thus has no more credibility than any other ancient manuscript, Homer's Iliad for example. Moreover, it is not a documentary or historical record; its purpose, rather, was to propagate the Christian faith. Did it never occur to Savidge that some or even many events described in the Bible could be pure products of imagination, invented only to impress those to be converted?

\section{Friedrich Katscher}

MariahilferStr. 133

A-1150 Vienna, Austria

1. Savidge, R. A. Nature 366,606 (1993).

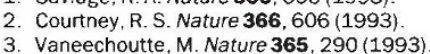

4. Cole, W. \& Sambhi, P. S. The Sikhs: Their Religious Beliefs and Practices (Routledge and Kegan Paul, London, 1984) Crossan, J. D. Jesus: A Revolutionary Biography (Harper. San Francisco, 1993).

6. Luke 10: $30-35$

SIR - I can go one better in cynicism than Ralph Estling (Nature 364, 754; 1993). Maybe religion is just a method by which the weak and the poor try to persuade the strong to be gentle and the rich to be generous, with a sizeable cut going to the persuaders. To make it work, supernatural powers and survival after death must be postulated. Otherwise there is no reason for anyone to listen to such appeals: the powerful are beyond punishment here and now.

The scam apparently works, as all human tribes have some kind of religion. Great cultures have been accompanied by impressive religions. Atheistic societies have left no trace in history. The one recent attempt to form a religionless culture in the Soviet Union has failed.

Andrejs Baidins

1104 Windon Drive,

Wilmington, Delaware 19803, USA
SIR - Having just read recent issues of Nature, I notice, with puzzled gloom, a letter advocating creationism. In the decades I have been a regular reader, I cannot recall that you ever printed a letter claiming that the Earth was flat, or that cattle disease was caused by malign sorcery; yet, ever and anon creationism has reared its silly head. Why, pray, is this particular variety of rubbish so uniquely privileged?

\section{Hammerton}

42 Honister Avenue, Jesmond,

Newcastle upon Tyne, NE2 3PA, UK

SIR - Sir Hermann Bondi (Nature 365, 484 ; 1993) asks how those who claim that "Christianity provided the necessary background for science" can account for "the fact that for three-quarters of the Christian era the home of science was confined to the non-Christian parts of the world". He ignores the work of many Christians in the early centuries that prepared the way for the achievements of the Renaissance. Thus, in the sixth century John Philoponus, a Christian Platonist who lived in Alexandria, wrote extensively on the material world. In his commentary on Aristotle's physics, his belief in creation led him to say, contrary to Aristotle, that projectiles move through the air because initially they are given a certain quantity of motion. He also rejected Aristotle's distinction between celestial and terrestrial matter. In these and other ways Christian beliefs led to the destruction of Aristotelian physics, thus opening the way to modern science.

Modern science is made possible by insistence on logical coherence and experimental verification. These were present in a qualitative way among the Greeks, and the vital contribution of the Christian Middle Ages was to refine these conditions into a more effective union by insisting on the quantitative precision that can be attained by using mathematics in the formulation of theories, and then verifying them not by observation alone but by precise measurements. This was achieved in the twelfth century, principally by Robert Grosseteste, one of the first chancellors of the University of Oxford, who is regarded as the founder of experimental science (see A. C. Crombie Robert Grosseteste and the Origins of Experimental Science 1100-1700, Clarendon Press, 1953). Subsequent work in Oxford by the Mertonian School, and in Paris by Buridan, Oresme and others, developed these early insights and spread them throughout Europe. This has been exhaustively documented by Duhem, Crombie, Maier, Jaki, Grant and many others. Thus it can be said that the foundations of modern science were laid in the Christian Middle Ages.

\section{P. E. Hodgson}

Corpus Christi College, Oxford OX1 4JF, UK 